Vol. 6 (1997): 161-172.

\title{
Effects of gradual replacement of rapeseed cake with linseed cake in a grass silage-based diet for dairy cows
}

\author{
Marketta Rinne, Seija Jaakkola \\ Agricultural Research Centre of Finland, Institute of Animal Production, FIN-31600 Jokioinen, Finland, \\ e-mail: marketta.rinne@mtt.fi \\ Matti Järvi \\ Koivikko Agricultural College, FIN-91500 Muhos, Finland \\ Pekka Huhtanen \\ Agricultural Research Centre of Finland, Institute of Animal Production, FIN-31600 Jokioinen, Finland
}

\begin{abstract}
Eight Finncattle cows were used in two replicated $4 \times 4$ Latin squares with 21-day periods to study the effects of replacing rapeseed cake with linseed cake in proportions of $0,1 / 3,2 / 3$ and 1 (on air dry basis), the total amount of supplement being $1.5 \mathrm{~kg} / \mathrm{day}$ (on air dry basis). The basal diet consisted of silage fed ad libitum and a $4.5 \mathrm{~kg} / \mathrm{day}$ (on air dry basis) barley:oats (1:1) mixture.

The experimental diets had no effect on feed intake. Effective protein degrability (EPD) determined by the nylon bag method was higher for linseed cake than for rapeseed cake. Milk production decreased linearly $(\mathrm{P}<0.01)$, from 18.5 to $17.1 \mathrm{~kg} / \mathrm{day}$, when the proportion of linseed cake was increased. Milk fat content increased $(\mathrm{P}<0.05)$ by $3.4 \mathrm{~g} / \mathrm{kg}$ but milk protein content tended to decrease $(\mathrm{P}<0.10)$ with an increase in linseed cake feeding. Despite clear differences in the fatty acid composition of linseed and rapeseed oils, experimental treatments had only minor effects on milk fatty acid composition.

Several factors, including the slightly higher ether extract content, higher EPD and/or lower amino acid content of linseed cake than rapeseed cake, the different fatty acid composition of the two supplements and the presence of antinutritional compounds in linseed cake, may be responsible for the impaired milk production with linseed cake feeding.
\end{abstract}

Key words: flaxseed, Linum usitatissimum L., milk production, milk fatty acid composition, oilseed cake

\section{Introduction}

Linseed or flaxseed (Linum usitatissimum L.) is one of the world's oldest and most versatile crops but its cultivation in Finland had almost ceased by the 1960s. A new interest in cultivating linseed, especially the oil linseed varieties, has emerged in the 1990s. Linseed oil and meal are recognised to be highly nutritious to humans whereas linseed oil can be used in paints and varnishes, and the fibre of oil linseed in techni-

(1) Agricultural and Food Science in Finland

Manuscript received February 1997 


\section{AGRICULTURAL AND FOOD SCIENCE IN FINLAND}

Rinne, M. et al. Linseed cake in a grass silage-based diet for cows

cally innovative developments in, for example, hard board production (van Kempen and Jansman 1994). Once the oil has been removed, linseed meal or cake can be used as animal feed. Rapeseed products are the most important protein supplements used in dairy cow feeding in Finland, and their effects on milk production have been extensively studied (e.g. Tesfa 1992, Tuori 1992). Knowledge of the value of linseed products is, however, more scarce. In a historical perspective, linseed-based feeds have been highly appreciated, but in more recent times a range of negative factors such as antinutritional compounds and the poor amino acid composition of linseed products have been reported (Olsson et al. 1988, van Kempen and Jansman 1994).

Apart from the interest in utilizing by-products of linseed oil production for feeding dairy cows, consumers are becoming increasingly aware of the health aspects of food and foods promoting health, i.e. functional foods. If milk fatty acid composition could be manipulated by feeding cows linseed oil, it might be possible to create special milk products with health-promoting effects. Rumen microbes are known to biohydrogenate dietary unsaturated fatty acids. Milk fatty acid composition can, however, be changed by feeding linseed oil to dairy cows (McDonald and Scott 1977, Kennelly 1996). Studies of typical Finnish dairy cow diets based on grass silage supplemented with locally produced linseed cake are, however, lacking.

The objective of this study, then, was to compare the production potential of linseed cake with that of rapeseed cake in milk production. Special attention was paid to the feasibility of altering milk fatty acid composition by feeding cows linseed cake.

\section{Material and methods}

\section{Animals and basal care}

Eight autumn-calving Finncattle cows, of which five were in their first lactation and three in their second lactation, were used. The cows had calved 70 (s.e. 8) days before the start of the experiment and their average live weight during the experiment was $468 \mathrm{~kg}$ (s.e. 17). They were fed and housed in individual stalls in the dairy barn at Koivikko Agricultural College. Grass silage was given twice daily ad libitum and concentrate feeds were offered as two equal meals at 06.30 and 14.30. The cows had free access to water, and a commercial mineral mixture was included according to their requirements.

\section{Experimental design}

The experiment was conducted as two replicated $4 \times 4$ Latin squares with periods of 21 days. The Latin squares were balanced for carry-over effects, within a square each treatment being once first and once preceeded by all other treatments. Experimental diets were formed by gradually replacing rapeseed cake (RC) with linseed cake (LC) as the protein supplement. The proportion of $\mathrm{LC}$ was $0,1 / 3,2 / 3$ and 1 in the four treatments. The total amount of protein supplementation was $1.5 \mathrm{~kg}$ of air dry feeds per animal/ day.

\section{Feeds}

The linseed cake was produced by Elixi Oil Ltd. and had been cold-pressed from oil linseed, variety Norlin. The rapeseed cake was a commercial heat-moisture -treated $\left(\right.$ Öpex $^{\circledR}$ ) product. The cows were also given a mixture of $4.5 \mathrm{~kg}$ (on air dry basis) of rolled barley and oats (1:1). Grass silage was produced from timothy-meadow fescue (4:1). It was ensiled in clamp silos with a formic acid-based additive (AIV 2) at a rate of 4 litres of formic acid per tonne of fresh grass.

\section{Measurements and sampling}

Data from the last week of each period were used to calculate concentrate intake. Silage intake was 
Vol. 6 (1997): 161-172.

measured over the last 3 days only, a relatively short period due to practical reasons. Representative feed samples were collected over each period of intake measurements. Fresh silage samples were stored at $-20^{\circ} \mathrm{C}$ before analysis. Samples of concentrate feeds were bulked over all periods, but silage samples were analysed separately for each period. Milk production was recorded during the last week of each period. Milk samples, in proportion to yield, were taken on the last four consecutive milkings of each period, and analysed for fat, protein and lactose using an infra-red milk analyser and for urea with an enzymatic UV test (Valio Ltd.). For milk fatty acid (FA) analyses, samples of two replicate animals were bulked.

\section{Chemical analyses}

The dry matter (DM) content of feed samples was determined by oven drying at $103^{\circ} \mathrm{C}$. Silage DM was corrected for loss of volatile substances [lactate, volatile fatty acids (VFA), ethanol and ammonia] according to Huida et al. (1986). The ash content of samples was obtained by ignition in a muffle furnace at $550^{\circ} \mathrm{C}$ for $6 \mathrm{~h}$. Concentrate feeds were analysed for nitrogen $(\mathrm{N})$ by the method of Sweeney (1989) on a Leco FP 428 nitrogen analyser, and fresh silage samples by the Kjeldahl method (EEC 1993). The crude protein (CP) content was obtained by multiplying the $\mathrm{N}$ content by 6.25 . Silages were analysed for water soluble carbohydrates (Somogyi 1945), lactate (Barker and Summerson 1941), VFA (Huida 1973), ethanol (Huida 1982) and ammonia N (McCullough 1967). Crude fibre (EEC 1992) and ether extract (EEC 1984; method A) analyses were conducted according to the official procedure for feed analysis. For concentrate feeds, the samples were treated with $\mathrm{HCl}$ before ether extraction (EEC 1984; method B with ethylether). Neutral detergent fibre (NDF) was determined according to Van Soest et al. (1991). Silage D-value was estimated in vitro with cellulase-based digestion (Friedel 1990).
To quantify individual milk FAs, milk fat was separated using the International Dairy Federation standard method and methylated as given in Antila and Kankare (1983). The methylated FAs were separated on an HP-Innowax (crosslinked PEG) column $(30 \mathrm{~m} \times 0.32 \mathrm{~mm}$, film thickness $0.5 \mu \mathrm{m}$ ) in a gas chromatograph Hewlett Packard 5890 fitted with a flame-ionization detector and an automatic injector (Hewlett Packard 7673). The carrier gas used was helium and the split ratio was 50:1. The injector and detector temperatures were 250 and $275^{\circ} \mathrm{C}$, respectively. The column temperature, which was $90^{\circ} \mathrm{C}$ at the start, was first raised to $105^{\circ} \mathrm{C}$ at a rate of $5^{\circ} \mathrm{C} / \mathrm{min}$, then to $225^{\circ} \mathrm{C}$ at a rate of $40^{\circ} \mathrm{C} /$ $\mathrm{min}$, and finally to $250^{\circ} \mathrm{C}$ at a rate of $2^{\circ} \mathrm{C} / \mathrm{min}$. Individual FAs and their mass fractions were identified using the milk fat standard CRM 164 (Pocklington et al. 1993).

\section{Feed values}

The metabolizable energy (ME) content of concentrate feeds was calculated from the chemical composition and the reported digestibility values (Tuori et al. 1996). Effective protein degradability (EPD) in the rumen was calculated for both protein supplements from nylon bag incubations of $0,2,4,8,16,24,48$ and $72 \mathrm{~h}$ in the rumen of three fistulated cows. Rapeseed cake was incubated as fed and LC was ground through a $6 \mathrm{~mm}$ sieve before incubation. After incubation the bags were washed in a household washing machine, dried at $60^{\circ} \mathrm{C}$ and analysed for $\mathrm{N}$. The values of amino acids absorbed from the small intestine (AAT) and the protein balance in the rumen (PBV) for the feeds were calculated according to Tuori et al. (1996) but the measured EPD values were used for RC and LC.

\section{Statistical analyses}

Data were analysed with the GLM procedure of 


\section{AGRICULTURAL AND FOOD SCIENCE IN FINLAND}

Rinne, M. et al. Linseed cake in a grass silage-based diet for cows

Table 1. Chemical composition and feed values of the feeds.

\begin{tabular}{lcrrr}
\hline & $\begin{array}{c}\text { Barley and } \\
\text { oats mixture }\end{array}$ & $\begin{array}{c}\text { Linseed } \\
\text { cake }\end{array}$ & $\begin{array}{c}\text { Rapeseed } \\
\text { cake }\end{array}$ & $\begin{array}{c}\text { Grass } \\
\text { silage }\end{array}$ \\
\hline Dry matter (DM), g/kg & 854 & 913 & 908 & 278 \\
In DM, g/kg & & & & \\
$\quad$ Ash & 25 & 59 & 64 & 77 \\
Crude protein & 137 & 359 & 342 & 164 \\
$\quad$ Ether extract & $51^{1)}$ & $160^{1)}$ & $117^{1)}$ & $43^{2}$ \\
$\quad$ Neutral detergent fibre & 250 & 213 & 279 & 520 \\
Feed values, g/kg DM & & & & \\
$\quad$ Metabolisable energy, MJ/kg DM & 13.0 & 14.1 & 12.8 & 10.9 \\
AAT $^{3)}$ & 100 & 95 & 149 & 84 \\
PBV $^{4)}$ & -25 & 207 & 115 & 20 \\
\hline
\end{tabular}

1) With $\mathrm{HCl}$ hydrolysis

${ }^{2)}$ Without $\mathrm{HCl}$ hydrolysis

${ }^{3)}$ Amino acids absorbed from the small intestine

${ }^{4)}$ Protein balance in the rumen

the Statistical Analyses System (SAS Institute Inc. 1989) using the following model:

$\begin{aligned} y_{i j k l}= & \mu+S_{i}+S(C)_{j}+P_{k}+T_{1}+(S \times P)_{i k}+(S \times T)_{i l} \\ & +e_{i j k l},\end{aligned}$

where $S$ is a square, $S(C)$ is a cow within a square, $\mathrm{P}$ is the period, $\mathrm{T}$ is the dietary treatment and $\mathrm{S} \times \mathrm{P}$ and $\mathrm{S} \times \mathrm{T}$ the subsequent interactions.

\section{Degradability of protein}

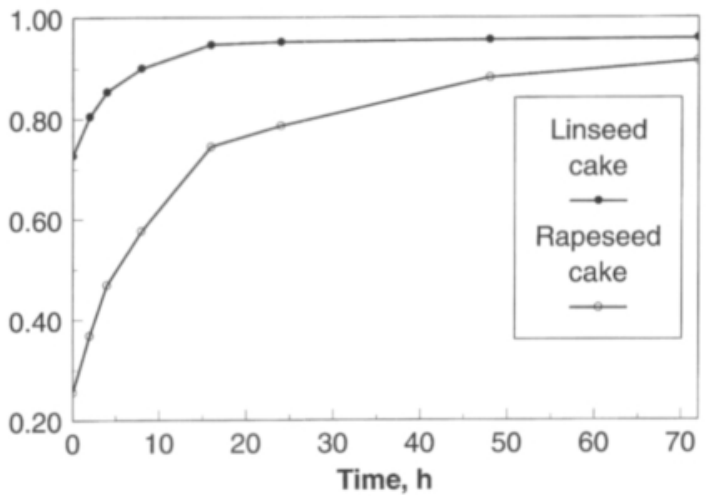

Fig. 1. Degradability of linseed cake and rapeseed cake protein incubated in nylon bags in the rumen of three replicate cows as a function of time.
The sums of squares for treatment effects were further separated, using orthogonal contrasts, into single degree of freedom comparisons of linear, quadratic and cubic effects of dietary LC increases. Quadratic and cubic effects were nonsignificant in virtually all cases. Consequently only linear effects are included in the tables.

\section{Results}

The composition of the feeds used in the present experiment is given in Table 1. The higher ether extract content of LC explains why its ME content was higher than that of RC. LC contained slightly more CP and clearly less NDF than RC. There was a marked difference in the protein values of the two supplements despite the small differences in CP content. This was due to the clearly higher EPD of LC than of RC $(0.88 \mathrm{vs}$ 0.61 ). Protein degradation curves for both supplements are presented in Figure 1. The silage clamp was changed in the middle of the experiment. The values describing the fermentation 


\section{AGRICULTURAL AND FOOD SCIENCE IN FINLAND}

Vol. 6 (1997): 161-172.

Table 2. Effects of gradual replacement of rapeseed cake with linseed cake on feed and nutrient intake.

\begin{tabular}{|c|c|c|c|c|c|c|}
\hline & \multicolumn{4}{|c|}{ Proportion of linseed cake } & \multirow[b]{2}{*}{ SEM } & \multirow{2}{*}{$\begin{array}{l}\text { Statistical } \\
\text { significance }\end{array}$} \\
\hline & 0 & $1 / 3$ & $2 / 3$ & 1 & & \\
\hline \multicolumn{7}{|l|}{ Feed intake, kg DM/d } \\
\hline Silage & 9.06 & 9.33 & 8.71 & 9.17 & 0.288 & ns \\
\hline Barley and oats mixture & 3.83 & 3.83 & 3.76 & 3.62 & - & \\
\hline Rapeseed cake & 1.37 & 0.91 & 0.45 & 0.00 & - & \\
\hline Linseed cake & 0.00 & 0.46 & 0.89 & 1.29 & - & \\
\hline Total & 14.26 & 14.53 & 13.81 & 14.08 & 0.343 & ns \\
\hline \multicolumn{7}{|l|}{ Nutrient intake, g/d } \\
\hline Organic matter, kg/d & 13.38 & 13.63 & 12.97 & 13.21 & 0.318 & ns \\
\hline Crude protein & 2461 & 2530 & 2418 & 2445 & 55.2 & ns \\
\hline \multicolumn{7}{|l|}{ Ether extract } \\
\hline Total & 743 & 769 & 759 & 786 & 17.7 & ns \\
\hline From rapeseed cake & 160 & 107 & 52 & 0 & - & \\
\hline From linseed cake & 0 & 73 & 143 & 207 & - & \\
\hline $\mathrm{AAT}^{1)}$ & 1349 & 1343 & 1260 & 1258 & 30.2 & $*$ \\
\hline $\mathrm{PBV}^{2)}$ & 223 & 292 & 316 & 335 & 8.9 & $* * *$ \\
\hline \multicolumn{7}{|c|}{ Metabolisable energy (ME), } \\
\hline $\mathrm{MJ} / \mathrm{d}$ & 166.4 & 168.9 & 162.0 & 165.9 & 4.02 & ns \\
\hline
\end{tabular}

quality of silage in the first and second halves of the experiment were: DM 229 and $328 \mathrm{~g} / \mathrm{kg}$, pH 4.78 and 4.14 , water soluble carbohydrates 9 and $93 \mathrm{~g} / \mathrm{kg}$ DM, lactate 44 and $29 \mathrm{~g} / \mathrm{kg} \mathrm{DM}$, acetic acid 33 and $11 \mathrm{~g} / \mathrm{kg}$ DM, butyric acid 2 and $0 \mathrm{~g} / \mathrm{kg} \mathrm{DM}$, ammonium $\mathrm{N} 79$ and $29 \mathrm{~g} / \mathrm{kg} \mathrm{N}$ and soluble N 525 and $645 \mathrm{~g} / \mathrm{kg} \mathrm{N}$. Values indicate that the first batch of silage was extensively fermented, with a rather high $\mathrm{pH}$, whereas the second batch was fermented to a restricted extent.

Dietary treatments had no effect on daily feed intake, but there were slightly more concentrate refusals when cows were fed high proportions of LC (Table 2). Organic matter, ME and CP intakes remained the same for all diets. Ether extract intake showed a slight numerical increase when more LC was fed, owing to an increase of $3.6 \mathrm{~g} / \mathrm{kg}(\mathrm{P}<0.001)$ in the ether extract content of the total diet. As a result of the difference in protein degradability characteristics between supplements, AAT intake was smaller $(\mathrm{P}<0.05)$ and PBV intake greater $(\mathrm{P}<0.001)$ on high $\mathrm{LC}$ diets.

Milk production $(\mathrm{P}<0.01)$ and energy corrected milk $(\mathrm{ECM})$ production $(\mathrm{P}<0.05)$ declined with an increasing proportion of LC in the diet (Table 3). The decrease was smaller for ECM than for milk $(5.6 \%$ vs $8.2 \%)$ because LC increased the milk fat content $(\mathrm{P}<0.05)$. The milk protein content tended to decrease $(\mathrm{P}<0.10)$ and the milk urea content increased $(\mathrm{P}<0.01)$ in high LC diets. The daily output of milk protein $(\mathrm{P}<0.001)$ and lactose $(\mathrm{P}<0.01)$ was clearly decreased by the gradual inclusion of LC but milk fat output was not significantly affected. The efficiency of dietary CP utilisation for milk protein was impaired $(\mathrm{P}<0.01)$ by a gradual increase of LC in the diet but feed conversion in terms of AAT, DM or ME into ECM was not affected by diet.

Gradual replacement of RC by LC had little effect on the milk short and medium chain $(\mathrm{C} 4: 0$ 


\section{AGRICULTURAL AND FOOD SCIENCE IN FINLAND}

Rinne, M. et al. Linseed cake in a grass silage-based diet for cows

Table 3. Effects of gradual replacement of rapeseed cake with linseed cake on milk production and milk composition and feed conversion.

\begin{tabular}{|c|c|c|c|c|c|c|}
\hline & \multicolumn{4}{|c|}{ Proportion of linseed cake } & \multirow[b]{2}{*}{ SEM } & \multirow{2}{*}{$\begin{array}{l}\text { Statistical } \\
\text { significance }\end{array}$} \\
\hline & 0 & $1 / 3$ & $2 / 3$ & 1 & & \\
\hline \multicolumn{7}{|l|}{ Milk produktion, $\mathrm{kg} / \mathrm{d}$} \\
\hline Milk & 18.5 & 18.2 & 17.2 & 17.1 & 0.38 & $* *$ \\
\hline $\mathrm{ECM}^{1)}$ & 20.7 & 20.6 & 19.7 & 19.6 & 0.43 & $*$ \\
\hline \multicolumn{7}{|l|}{ Milk composition, $\mathrm{g} / \mathrm{kg}$} \\
\hline Protein & 33.5 & 33.8 & 33.1 & 32.5 & 0.43 & o \\
\hline Fat & 43.6 & 44.8 & 46.4 & 47.0 & 0.85 & $*$ \\
\hline Lactose & 49.1 & 48.5 & 49.0 & 49.0 & 0.20 & ns \\
\hline Milk urea, mmol/l & 6.08 & 6.32 & 6.83 & 6.70 & 0.153 & $* *$ \\
\hline \multicolumn{7}{|l|}{ Output in milk, g/d } \\
\hline Protein & 617 & 617 & 558 & 549 & 15.9 & $* * *$ \\
\hline Fat & 808 & 824 & 787 & 798 & 25.3 & ns \\
\hline Lactose & 906 & 888 & 827 & 829 & 25.7 & $*$ \\
\hline \multicolumn{7}{|l|}{ Efficiency of feed conversion } \\
\hline Protein output/CP intake & 0.252 & 0.245 & 0.232 & 0.226 & 0.0063 & $* *$ \\
\hline $\mathrm{g} \mathrm{AAT}^{21} / \mathrm{kg} \mathrm{ECM}$ & 49.2 & 50.0 & 48.0 & 47.6 & 1.62 & ns \\
\hline $\mathrm{ECM} / \mathrm{DM}$ intake & 1.46 & 1.42 & 1.44 & 1.41 & 0.034 & ns \\
\hline $\mathrm{ME}, \mathrm{MJ} / \mathrm{kg} \mathrm{ECM}$ & 5.55 & 5.81 & 5.73 & 5.89 & 0.212 & ns \\
\hline
\end{tabular}

to $\mathrm{C} 16: 0)$ FA composition other than a tendency $(\mathrm{P}<0.10)$ for the $\mathrm{C} 14: 1$ proportion to decrease (Table 4). In contrast, C16:1 and C20:0 decreased $(\mathrm{P}<0.001$ and $\mathrm{P}<0.01$, respectively $)$ while $\mathrm{C} 18: 0$ and $\mathrm{C} 18: 3$ increased $(\mathrm{P}<0.01$ and $\mathrm{P}<0.05$, respectively). At high LC levels, the proportion of C18:1 tended to decrease $(\mathrm{P}<0.10)$. Furthermore $\mathrm{LC}$ increased the degree of milk FA saturation $(\mathrm{P}<0.05)$.

\section{Discussion}

\section{Milk production}

Gradual replacement of RC with LC led to a significant decrease in the milk production of the cows. When cereal-based (usually a mixture of rolled barley and oats) concentrates have been replaced, by weight, with rapeseed feeds in Finnish feeding experiments, the production responses have, on average, been $1.07 \mathrm{~kg}$ milk or $39.9 \mathrm{~g}$ milk protein per $\mathrm{kg}$ DM replaced (Ahvenjärvi et al. 1995). Here, the response to replacement of LC with RC resulted in $1.03 \mathrm{~kg}$ milk, $0.81 \mathrm{~kg}$ ECM and $50 \mathrm{~g}$ milk protein output per day per $\mathrm{kg}$ DM replaced. These figures reveal that the production potential of LC is basically the same as that of cereal-based concentrates.

In a Swedish experiment using similar feeds, milk production was impaired to a similar extent. Replacement of RC with LC resulted in $0.57 \mathrm{~kg}$ less milk and $26 \mathrm{~g}$ less milk protein per $\mathrm{kg}$ DM replaced (Bertilsson et al. 1994). Kennelly (1996) reported two Canadian experiments investigating full fat linseed. In the first experiment, in which the whole linseed content of the diet was gradually increased $(0,50,100$ and 150 
Vol. 6 (1997): 161-172.

Table 4. Effects of gradual replacement of rapeseed cake with linseed cake on milk fatty acid composition $(\mathrm{g} / \mathrm{kg})$.

\begin{tabular}{|c|c|c|c|c|c|c|}
\hline & \multicolumn{4}{|c|}{ Proportion of linseed cake } & \multirow[b]{2}{*}{ SEM } & \multirow{2}{*}{$\begin{array}{l}\text { Statistical } \\
\text { significance }\end{array}$} \\
\hline & 0 & $1 / 3$ & $2 / 3$ & 1 & & \\
\hline $\mathrm{C} 4: 0$ & 33.3 & 34.6 & 33.9 & 34.5 & 0.62 & ns \\
\hline C6:0 & 23.4 & 23.3 & 23.3 & 24.0 & 0.39 & ns \\
\hline C8:0 & 13.6 & 13.2 & 13.2 & 13.6 & 0.37 & ns \\
\hline C10:0 & 29.0 & 28.0 & 28.2 & 28.3 & 0.92 & ns \\
\hline C10:1 & 2.2 & 4.2 & 1.3 & 1.7 & 0.95 & ns \\
\hline $\mathrm{C} 12: 0$ & 32.0 & 30.7 & 30.8 & 30.7 & 1.08 & ns \\
\hline C12:1 & 0.3 & 0.6 & 0.4 & 0.4 & 0.15 & ns \\
\hline C13:0 & 1.5 & 1.5 & 1.3 & 1.4 & 0.11 & ns \\
\hline $\mathrm{C} 14: 0$ & 109.8 & 107.6 & 109.0 & 108.0 & 1.65 & ns \\
\hline C14:1 & 10.2 & 9.9 & 9.4 & 9.3 & 0.29 & o \\
\hline C15:0 & 14.6 & 14.2 & 14.1 & 14.3 & 0.36 & ns \\
\hline $\mathrm{C} 16: 0$ & 299.3 & 298.6 & 301.9 & 304.0 & 3.86 & ns \\
\hline C16:1 & 17.3 & 16.7 & 15.8 & 15.9 & 0.16 & $* * *$ \\
\hline C17:0 & 10.3 & 10.7 & 10.6 & 10.5 & 0.19 & ns \\
\hline C17:1 & 2.6 & 2.5 & 2.5 & 2.4 & 0.07 & o \\
\hline C18:0 & 115.6 & 120.8 & 128.0 & 128.0 & 1.93 & $* *$ \\
\hline C18:1 & 239.6 & 243.1 & 236.5 & 232.4 & 2.77 & o \\
\hline C18:2 & 27.0 & 27.3 & 27.3 & 27.4 & 1.05 & ns \\
\hline C18:3 & 4.8 & 5.7 & 5.7 & 6.0 & 0.23 & $*$ \\
\hline Saturated total & 685.6 & 686.4 & 697.2 & 700.4 & 4.16 & $*$ \\
\hline $\mathrm{C} 16: 0 / \mathrm{C} 18$ total & 0.769 & 0.753 & 0.755 & 0.770 & 0.0174 & ns \\
\hline
\end{tabular}

$\mathrm{SEM}=$ Standard error of the mean; Statistical significance: ${ }^{* * *}(\mathrm{P}<0.001),{ }^{* *}(\mathrm{P}<0.01),{ }^{*}(\mathrm{P}<0.05), 0(\mathrm{P}<0.10)$

$\mathrm{g} / \mathrm{kg}$ DM), milk production and milk fat content were unaffected but the milk protein content decreased linearly. Thus little benefit was derived from feeding linseed with high protein and high energy contents in preference to other protein supplements which generally elicit rather high production responses. In the second experiment, a diet with no supplemental fat was compared with one including $100 \mathrm{~g} / \mathrm{kg}$ of whole linseeds, rolled linseeds or a mixture of rolled linseeds and rapeseeds. There were virtually no differences in the production results of the last two diets, which are comparable to those fed in the current experiment. Milk yield was similar in both these diets and the control diet, but feeding whole linseeds significantly lowered milk production. In another Canadian experiment (Khorasani et al. 1994), linseed meal feeding maintained the same milk production as rapeseed meal, but the experimental feeds and basal diet were not comparable to those in our experiment, as the oilseed products were solvent extracted and fed in a whole crop oat silage-based total mixed ration.

In the present experiment, there are several potential causes for the reduced production potential of LC compared with RC: the slightly higher ether extract content of LC, which may have resulted in decreased diet digestibility; differences in FA composition; more extensive ruminal degradability of LC; differences in the amino acid profile; and, possibly, antinutritional factors contained in linseeds.

The linseed cake used here had a higher ether extract content than had RC. This particular rapeseed product was chosen as the reference feed, because it had the highest ether extract content of the domestic rapeseed products commercially available. The detrimental effects of high fat diets on rumen fermentation are well document- 
Rinne, M. et al. Linseed cake in a grass silage-based diet for cows

ed. Decreased cellulolytic activity in the rumen would be highly detrimental in diets based extensively on silage, such as in the present experiment, in which 0.64 of diet DM derived from silage, which is high in potentially digestible fibre. A high dietary fibre content may, conversely, diminish the detrimental effects of FA feeding (Jenkins 1993).

Assuming that decreased digestibility on the LC diet was the reason for reduced milk output and that the efficiency of energy utilisation for milk production remained the same, OM digestibility should have declined by $25 \mathrm{~g} / \mathrm{kg}$ DM. The level of ether extract supplementation was rather low in our experiment and the increase with an increasing proportion of LC was negligible, $47 \mathrm{~g} /$ day or from $52.3 \mathrm{~g} / \mathrm{kg}$ diet DM on an all$\mathrm{RC}$ diet to $55.9 \mathrm{~g} / \mathrm{kg} \mathrm{DM}$ on an all-LC diet. Studies reporting negative effects of fat have generally used higher levels of fat feeding (Palmquist 1984, Tesfa 1992, Wu and Huber 1994), while Palmquist (1976) suggested a $50 \mathrm{~g} / \mathrm{kg}$ safety limit in dairy cow rations.

The FA composition of the two oilseeds also differs. Rapeseed oil contains high levels of oleic acid (C18:1), but linseed oil is high in linolenic acid (C18:3). In Sweden, the contents of oleic and linolenic acids in RC were 561 and $97 \mathrm{~g} / \mathrm{kg}$, and in LC 155 and $551 \mathrm{~g} / \mathrm{kg}$, respectively (Bertilsson et al. 1994). Finnish rapeseed oil contained $411 \mathrm{~g} / \mathrm{kg}$ oleic acid and $73 \mathrm{~g} / \mathrm{kg}$ linolenic acid (Tesfa 1992), the respective values for Finnish linseed oil being 172 and $619 \mathrm{~g} / \mathrm{kg}$ (Elixi Oil Ltd., personal communication). On the basis of Finnish reference values, the LC diet resulted in $30 \mathrm{~g}$ lower $\mathrm{C} 18: 1$ intake but $116 \mathrm{~g}$ higher $\mathrm{C} 18: 3$ intake per day. Rumen protozoa are especially vulnerable to the presence of free FAs, and Doreau and Ferlay (1995) suggested, that linseed oil has a more negative effect than other sources of lipid on rumen protozoal number, possibly due to the higher C18:3 content of linseed oil than of other fat sources. The claim has, however, yet to be substantiated.

If the protozoal population had been decreased by LC feeding, it would still be difficult to reconcile the current results. The role of pro- tozoa in digestion is not fully understood, as pointed out by Itabashi et al. (1990). Defaunation may improve the nutritional status of the host animal on a low protein diet but usually protozoa are considered useful to the ruminant. The proportion of butyric acid has been observed to decrease concomitantly with a decline in the protozoal population (Ikwuegbu and Sutton 1982, Sutton et al. 1983, Itabashi et al. 1990, Broudiscou and Lassalas 1991) and butyric acid generally promotes milk fat synthesis. Here, LC feeding resulted in a significant increase in milk fat content, which does not support the speculation of low butyrate production in the rumen as a result of potentially decreased rumen protozoal numbers.

The non-ammonia-nitrogen flow to the duodenum increased in sheep fed $43 \mathrm{~g}$ (Ikwuegbu and Sutton 1982), $77 \mathrm{~g}$ (Sutton et al. (1983) or $60 \mathrm{~g}$ (Broudiscou et al. 1994) of linseed oil in diet DM. The smaller protozoal population probably contributed, a suggestion supported by data of Broudiscou et al. (1994), who used defaunated sheep as a reference. Broudiscou and Lassalas (1991) reported that use of rumen fluid from sheep given linseed oil at a rate of $60 \mathrm{~g} / \mathrm{kg}$ diet DM reduced the degradability of amino acids in vitro. Doreau and Ferlay (1995) argued that lipids have not been shown to decrease total bacterial populations nor non-cellulolytic strains in the rumen, so the above finding does not necessarily apply in vivo. The level of linseed oil supplementation in the present experiment was lower than in the studies mentioned earlier, being only $15 \mathrm{~g} / \mathrm{kg}$ diet DM at the highest inclusion level.

Differences in diet DM ether extract (both amount and FA composition) may have partly accounted for the impaired milk production, but it seems unlikely that these differences could be of major importance.

Both oilseed cakes were almost identical in terms of CP content, but the rumen degradability of CP differed markedly. Linseed protein has been found to degrade rapidly in the rumen (Bertilsson et al. 1994, Moss and Givens 1994), a conclusion we also reached. The heat-moisture treatment of RC used may have further impaired 
Vol. 6 (1997): 161-172.

the rumen degradability of its protein, but such treatment has not been shown to improve the production potential of the feed compared with that of untreated rapeseed products (Tuori 1992, Huhtanen and Heikkilä 1996). It is, however, possible that the higher EPD of LC refers to a certain feature in the feed owing to which its production potential is lower than that of RC. Calculated AAT balance (supply/requirement) was adequate in all diets $(1.03,1.04,1.01$ and 1.01 as proportion of LC increased). Moreover, all diets gave the cows sufficient $\mathrm{N}$, as indicated by an average diet DM CP content of $174 \mathrm{~g} / \mathrm{kg}$ $\mathrm{DM}$ and a high milk urea content averaging 6.48 $\mathrm{mmol} / \mathrm{l}$.

The amino acid composition of linseed protein is poorer than that of rapeseed protein in terms of the essential amino acids, lysine, methionine, threonine and histidine (Bertilsson et al. 1994, van Kempen and Jansman 1994, Tuori et al. 1996). Susmel et al. (1994) reported a relatively low amino acid content of LC protein $(693 \mathrm{~g} / \mathrm{kg})$ and also a rather low biological value of LC protein as measured in hamsters (70).

New information on the role of individual amino acids in the metabolism of dairy cows fed grass silage-based diets has recently accumulated at our Institute. Histidine seems to be the first limiting amino acid in diets similar to those tested in the current experiment (Vanhatalo et al. 1997). If we assume that the histidine content of $\mathrm{RC}$ was $2.8 \mathrm{~g} / 100 \mathrm{~g} \mathrm{CP}$ and that of LC $2.1 \mathrm{~g} / 100$ $\mathrm{g} \mathrm{CP}$ (Tuori et al. 1996) and further that the EPD of histidine is similar to that of $\mathrm{CP}$, intestinal histidine supply would have been $3.9 \mathrm{~g} /$ day higher on the RC diet than on the LC diet. An increase in histidine supply to the mammary has led to an improvement in milk production and lower milk fat content (Vanhatalo et al. 1997), as was observed here, too, when the proportion of LC in the diet decreased. Inclusion of LC caused a decrease of $12.4 \%$ in milk protein yield, $1.3 \%$ in fat yield and $9.3 \%$ in lactose yield compared with RC-based diets. These figures suggest that mammary amino acid supply or balance may have been an important contributer to the results obtained.
Linseeds are known to contain certain poisonous or antinutritional factors such as the cyanogenic glucosides, linamarin, lotaustarin, linustatin and neolinustatin (see Olsson et al. 1988, van Kempen and Jansman 1994). Several rumen microbes are able to break down linamarin (Majak and Cheng 1987), which leads to the production of highly toxic hydrogen cyanide. Toxic compounds may affect either the microbes in the rumen or the host metabolism. In our experiment, we did not attempt to clarify the possible toxic effects of linseed feeding, and their contribution to the impaired production cannot be totally excluded.

\section{Milk fatty acid composition}

Milk FA composition is influenced by the profile of FAs circulating in the blood stream. Dietary effects of FA supplementation on milk FA composition depend on the extent to which dietary FAs escape rumen microbial hydrogenation (Grummer 1991). Here, the content of C18:1 tended to decrease and that of C18:3 increased with increasing LC feeding, reflecting the changes in dietary FA intake. These changes were, however, of minor impact. If we assume similar C18:3 intakes from the basal diet, the approximate intake of C18:3 on the all-LC diet was 116 $\mathrm{g} /$ day higher than on the RC diet. The difference in milk output of $\mathrm{C} 18: 3$ was $0.8 \mathrm{~g} / \mathrm{day}$, leading to an extraction rate of only $0.07 \%$. It is apparent that $\mathrm{C} 18: 3$ was almost totally hydrogenated to $\mathrm{C} 18: 0$ in the rumen. Subsequent intestinal and mammary desaturase activity resulted in high C18:1 outputs in milk, such as are generally observed when any FAs containing 18 carbon units (C18) are fed in dairy rations (Grummer 1991). The milk FA profile was very similar in all diets owing to the similar intakes of C18 FA. The ratio of $\mathrm{C} 16: 0$ to $\mathrm{C} 18 \mathrm{FA}$ in milk has been used to describe the potency of milk to affect human blood cholesterol levels (Grummer 1991). We noted no differences. C18:1 was not analytically separated into different positional isomers, but it is possible that partial hydrogenation of $\mathrm{C} 18: 3$ 


\section{AGRICULTURAL AND FOOD SCIENCE IN FINLAND}

Rinne, M. et al. Linseed cake in a grass silage-based diet for cows

in the rumen led to a greater accumulation of trans isomers of C18:1 and C18:2 (Grummer 1991) in cows on LC diets than in those on RC diets.

Other researchers have been able to markedly affect milk FA composition when comparing diets with no additional lipid supplementation and those containing linseed oil. McDonald and Scott (1977) reported that feeding approximately $80 \mathrm{~g} / \mathrm{kg}$ linseed oil protected from rumen $\mathrm{mi}-$ crobes by formaldehyde-treated casein increased the milk C18:3 content dramatically from 10 to $220 \mathrm{~g} / \mathrm{kg}$. A gradual increase in whole full fat linseed from 0 to $150 \mathrm{~g} / \mathrm{kg}$ DM raised the total C18 FA content from 316 to $476 \mathrm{~g} / \mathrm{kg}$ and C18:3 from 8 to $12 \mathrm{~g} / \mathrm{kg}$ (Kennelly 1996). Comparison of rolled linseed with a mixture of rolled linseed and rapeseed offered at a level of $100 \mathrm{~g} / \mathrm{kg} \mathrm{DM}$ resulted in a decrease in C18:0 (124 vs $143 \mathrm{~g} / \mathrm{kg}$ ), but both $\mathrm{C} 18: 2$ (31 vs $24 \mathrm{~g} / \mathrm{kg}$ ) and $\mathrm{C} 18: 3$ $(10 v s 8 \mathrm{~g} / \mathrm{kg}$ ) were higher on the all-linseed diet (Kennelly 1996). Similarly, comparison of RC and LC led to negligible but significant increases in C18:3, from 7 to $9 \mathrm{~g} / \mathrm{kg}$ (Bertilsson et al. 1994). In conclusion, the content of C18:0 and C18:1 in milk can be increased to a certain extent by feeding cowss unprotected linseed products, i. e. by increasing their total intake of any C18 FA, but if the content of C18:3 needs to be increased considerably, FAs need to be protected from biohydrogenation in the rumen. Note, however, that increased unsaturation of milk FAs increases the risk of oxidation and instability of milk and milk products and may impair their sensory quality.

\section{Conclusions}

The results of the present experiment suggest that linseed cake is less suitable than rapeseed cake for dairy cow feeding. If linseed cultivation continues to expand and/or demand for milk produced by linseed feeding to increase, it may be necessary to evaluate the effects of linseed processing on milk production. Linseed products could benefit from decreased ruminal protein degradability, and antinutritional factors could probably be reduced in the process. To overcome the possible negative effects of linseed FAs on rumen microbes (Sutton et al. 1983) and to amplify changes in milk FA composition (McDonald and Scott 1977), it might be beneficial to protect linseed oil from rumen microbial interference.

Acknowledgements. We gratefully acknowledge the contribution of Ossi Heikkinen, Leea Kuortti, Sanna Tauriainen, Päivi Tikkala and Jarkko Ylikangas, students at Koivikko Agricultural College. We also thank Vesa Toivonen and his staff for their skilful laboratory analyses. We are grateful to Elixi Oil Ltd. for the protein feeds and partial financial support.

\section{References}

Ahvenjärvi, S., Huhtanen, P. \& Varvikko, T. 1995. Kotimainen rypsirouhe lypsylehmien valkuaisrehuna (Finnish rapeseed meal as a protein supplement for dairy cows, in Finnish). Agro-Food '95. Tampere, Finland. Abstract B33. ISBN 951-808-036-4.

Antila, V. \& Kankare, V. 1983. Fatty acid composition of milk lipids. Milchwissenchaft 38: 478-480.

Barker, S.B. \& Summerson, W.H. 1941. The colorimetric determination of lactic acid in biological materials. Journal of Biological Chemistry 138: 537-554.

Bertilsson, J., Emanuelson, M. \& Murphy, M. 1994. Linfröprodukter som foder till mjölkkor. Summary: Linseed products for dairy cows. Report 229. 24 p.
Swedish University of Agricultural Sciences, Department of Animal Nutrition and Management, Uppsala. ISSN 0347-9838

Broudiscou, L. \& Lassalas, B. 1991. Linseed oil supplementation of the diet of sheep: effect on the in vitro fermentation of amino acids and proteins by rumen microorganisms. Animal Feed Science and Technology 33: 161-171.

- , Pochet, S. \& Poncet, C. 1994. Effect of linseed oil supplementation on feed degradation and microbial synthesis in the rumen of ciliate-free and refaunated sheep. Animal Feed Science and Technology 49: 189-202. 


\title{
AGRICULTURAL AND FOOD SCIENCE IN FINLAND
}

\author{
Vol. 6 (1997): 161-172.
}

Doreau, M. \& Ferlay, A. 1995. Effect of dietary lipids on nitrogen metabolism in the rumen: a review. Livestock Production Science 43: 97-110.

EEC. 1984. Comission Directive 84/4/EEC. Determination of crude fats and oils. Official Journal of the European Communities No L 15/28-30.

- 1992. Comission Directive 92/89/EEC. Determination of crude fibre. Official Journal of the European Communities No L 344/35-37.

- 1993. Comission Directive 93/28/EEC. Determination of crude protein. Official Journal of the European Communities No L 179/8-10.

Friedel, K. 1990. Die Schătzung des energetischen Futterwertes von Grobfutter mit Hilfe einer cellulasemethode. Wissenschaftliche Zeitung Universitet Rostock, N-Reihe 39: 787-86.

Grummer, R.R. 1991. Effect of feed on the composition of milk fat. Journal of Dairy Science 74: 3244- 3257.

Huhtanen, P. \& Heikkilä, T. 1996. Effects of physical treatment of barley and rapeseed meal in dairy cows given grass silage-based diets. Agricultural and Food Science in Finland 5: 399-412.

Huida, L. 1973. Quantitative determination of volatile fatty acids from rumen sample and silage by gas-liquid chromatography. Journal of the Scientific Society of Agricultural Science in Finland 45: 483-488.

- 1982. Gas chromatographic determination of water and ethanol in silage by internal standard method. Journal of the Scientific Agricultural Society in Finland 54: 137-143.

- , Väătăinen, H. \& Lampila, M. 1986. Comparison of dry matter contents in grass silages as determined by oven drying and gas chromatographic water analysis. Annales Agriculturae Fenniae 25: 215-230.

Ikwuegbu, O.A. \& Sutton, J.D. 1982. The effect of varying the amount of linseed oil supplementation on rumen metabolism in sheep. British Journal of Nutrition 48: 365-375.

Itabashi, H., Kobayashi, T., Takenka, A. \& Matsumoto, M. 1990. Effect of protozoa on nutritional characteristics of ruminant. In: Hoshino, S. et al. (eds.). The Rumen Ecosystem. Japan Scientific Series Press, Tokyo, Japan. 223 p.

Jenkins, T.C. 1993. Lipid metabolism in the rumen. Journal of Dairy Science 76: 3851-3863.

Kempen, G.J.M. van \& Jansman, A.J.M. 1994. Use of EC produced oil seeds in animal feeds. In: Garnsworthy, P.C. \& Cole, D.J.A. (eds). Recent Advances in Animal Nutrition. Nottingham University Press, Nottingham, UK. p. 31-56. ISBN 1-897676-018

Kennelly, J.J. 1996. The fatty acid composition of milk fat as influenced by feeding oilseeds. Animal Feed Science and Technolgy 60: 137-152.

Khorasani, G.R., Robinson, P.H. \& Kennelly, J.J. 1994. Evaluation of solvent and expeller linseed meals as protein sources for dairy cattle. Canadian Journal of Animal Science 74: 479-485.

Majak, W. \& Cheng, K.-J. 1987. Hydrolysis of the cyanogenic glucosides amygdalin, prunasin and linamarin by ruminal microorganisms. Canadian Journal of Animal Science 67: 1133-1137.

McCullough, H. 1967. The determination of ammonia in whole blood by direct colorimetric method. Clinica Chimica Acta 17: 297-304.

McDonald, I.W. \& Scott, T.W. 1977. Foods of ruminant origin with elevated content of polyunsaturated fatty acids. World Review of Nutrition and Dietetics 26: 144-207.

Moss, A.R. \& Givens, D.I. 1994. The chemical composition, digestibility, metabolisable energy content and nitrogen degradability of some protein concentrates. Animal Feed Science and Technology 47: 335- 351.

Olsson, A.-C., Emanuelsson, M. \& Wiktorsson, H. 1988. Linfröets egenskaper och användbarhet som foder. Summary: The properties of flaxseed and its subsequent use in feeding. Report 173. 30 p. Swedish University of Agricultural Sciences, Department of Animal Nutrition and Management, Uppsala. ISBN 91-576-3451-3

Palmqvist, D.L. 1976. A kinetic concept of lipid transport in ruminants. A review. Journal of Dairy Science 59: 355-363.

- 1984. Use of fats in diets for lactating dairy cows. In: Wiseman, J. (ed.). Fats in Animal Nutrition. Butterworths, London. p. 357-381. ISBN 0-408-10864-9

Pocklington, W.D., Pearse, J., Muuse, B.G., Lognay, G., Boenke, A., Schurer, B. \& Wagstaffe, P.J. 1993. Certification of the fatty acid profile and mass fraction of butyric acid ( $n$-butnoic acid), cholesterol and three individual sterols of an anhydrous milk fat reference material with values for information of triglycerids, minor fatty acids, added vanillin and 'total' sterol mass fraction. Report EUR 15277 EN, Commission of European Communities, Community Bureau of Reference. Luxembourg. $116 \mathrm{p}$.

SAS Institute Inc. 1989. SAS/STAT User's Guide, Version 6, Fourth edition, Volume 1. Cary, NC. 943 p. ISBN 1-55544-376-1

Sjaunja, L.O., Baevre, L., Junkkarinen, L., Pedersen, J. \& Setălă, J. 1990. A Nordic proposal for an energy corrected milk (ECM) formula. 27 $7^{\text {th }}$ Session International Committee of Recording and Productivity of Milk Animals. July 2.-6. Paris, France. p. 156-157.

Somogyi, M. 1945. A new reagent for the determination of sugars. Journal of Biological Chemistry 160: 6168.

Susmel, P., Antongiovanni, M., Stefanon, B., Mills, C.R., Hindle, V.A. \& Vurren, A.M. van. 1994. Biological and chemical assessment of feed proteins before and after rumen exposure. Animal Feed Science and Technology 49: 119-132.

Sutton, J.D., Knoght, R., McAllan, A.B. \& Smith, R.H. 1983. Digestion and synthesis in the rumen of sheep given diets supplemented with free and protected oils. British Journal of Nutrition 49: 419-432.

Sweeney, R.A. 1989. Generic combustion method for determination of crude protein in feeds: Collaborative study. Journal of the Association of Official Analytical Chemistry 72: 770-774.

Tesfa, A.T. 1992. Rapeseed oil in ruminants diet: Its effect on rumen metabolism and animal performance. Academic dissertation. University of Helsinki, Department of Animal Science. $53 p+5$ articles. ISBN 95290-3786-4 


\title{
AGRICULTURAL AND FOOD SCIENCE IN FINLAND
}

Rinne, M. et al. Linseed cake in a grass silage-based diet for cows

Tuori, M. 1992. Rapeseed meal as a supplementary protein for dairy cows on grass silage-based diet, with the emphasis on the Nordic AAT-PBV feed protein evaluation system. Agricultural Science in Finland 1: 367-439.

-, Kaustell, K., Valaja, J., Aimonen, E., Saarisalo, E. \& Huhtanen, P. 1996. Rehutaulukot ja ruokintasuositukset (Feed tables and nutrient recommendations, in Finnish). $2^{\text {nd }}$ ed. Yliopistopaino, Helsinki. 99 p. + 3 encl. ISBN 951-45-348-X

Vanhatalo, A., Huhtanen, P. \& Varvikko, T. 1997. Response of dairy cows fed grass silage based diets to the abomasal infusions of histidine alone or in combinations with methionine and lysine. Journal of Dairy Science 80, Suppl. 1: 257 (Abstract P441).

Van Soest, P.J., Robertson, J.B. \& Lewis, B.A. 1991. Methods for dietary fiber, neutral detergent fiber, and nonstarch polysaccharides in relation to animal nutrition. Journal of Dairy Science 74: 3583-3597.

Wu, Z. \& Huber, J.T. 1994. Relationship between dietary fat supplementation and milk protein concentration in lactating cows: A review. Livestock Production Science 39: 141-155.

\section{SELOSTUS}

\section{Rypsipuristeen asteittainen korvaaminen pellavapuristeella lypsylehmien säilörehuun perustuvassa ruokinnassa}

\author{
Marketta Rinne, Seija Jaakkola, Matti Järvi ja Pekka Huhtanen \\ Maatalouden tutkimuskeskus ja Koivikon maatalousoppilaitos
}

Lypsylehmien ruokintatutkimuksessa rypsipuristetta korvattiin asteittain pellavapuristeella siten, että pellavapuristeen osuus oli $0,1 / 3,2 / 3$ tai 1 valkuaisrehusta, jonka määrä oli yhteensä $1,5 \mathrm{~kg}$ ilmakuivaa rehua päivässä. Koerehujen lisäksi lehmille annettiin $4,5 \mathrm{~kg} / \mathrm{pv}$ ohran ja kauran seosta ja vapaasti nurmisäilörehua. Kokeessa oli 8 Koivikon maatalousoppilaitoksen suomenkarjalehmää.

Koeruokinnat eivät vaikuttaneet rehujen syöntiin. Nailonpussiuitoin määritetty valkuaisen pötsihajoavuus oli pellavapuristeessa suurempi kuin rypsipuristeessa, mikä johti pienempään ohutsuolesta imeytyvien aminohappojen saantiin mutta suurempaan pötsin valkuaistaseeseen ruokinnoilla, joissa pellavapuristeen osuus oli suuri.

Maitotuotos pieneni suoraviivaisesti 18,5:stä 17,1 kg:aan/pv, kun pellavapuristeen osuus lisääntyi. Maidon rasvapitoisuus suureni $3,4 \mathrm{~g} / \mathrm{kg}$, mutta maidon valkuaispitoisuus pieneni lievästi pellavapuristeen li- sääntyneen syötön myötä. Pellavapuristeen lisäys ei vaikuttanut päivittäiseen maitorasvan tuotantoon, mutta maitovalkuaisen tuotanto väheni $68 \mathrm{~g} / \mathrm{pv}$. Maidon ureapitoisuus lisääntyi pellavapuristeen lisäyksen myötä. Rypsi- ja pellavaöljyn rasvahappokoostumuksen selkeästä erosta huolimatta muutokset maidon rasvahappokoostumuksessa olivat erittäin pieniä.

Pellavapuristeen hieman suurempi rasvapitoisuus, rasvahappokoostumus, valkuaisen suuri pötsihajoavuus ja/tai heikko aminohappokoostumus sekä mahdolliset haitta-aineet ovat voineet vaikuttaa pellavapuristeen rypsipuristetta heikompaan tuotantovaikutukseen. Mikäli öljypellavan viljely lisääntyy entisestään tai pyritään tuottamaan terveysvaikutteisia maitotuotteita, joissa pellavaöljyn rasvahappoja halutaan siirtää maitoon, kannattaisi selvittää pellavapuristeen prosessoinnin vaikutuksia tuotantovaikutukseen ja rasvahappojen suojaamiseen pötsimikrobien muokkaukselta. 